\title{
IMPLEMENTASI ASSET PROTECTION LENDING RATIONALE PADA PEMBIAYAAN KORPORASI DI BANK SYARIAH (STUDI IN BANK SYARIAH MANDIRI)
}

\section{IMPLEMENTATION OF ASSET PROTECTION LENDING RATIONALE CORPORATE FINANCING IN ISLAMIC BANK (STUDY IN BANK SYARIAH MANDIRI)}

\author{
Rani Alfiani1a; Rully Trihantana2; T. Rifqy Thantawi ${ }^{3}$ \\ 1aProgram Studi Ekonomi Syariah Fakultas Ekonomi Islam Universitas Djuanda, Jl. Tol \\ Ciawi No. 1, Kotak Pos 35 Bogor 16720, E-mail: rani.alfiani@unida.ac.id \\ 2Program Studi Perbankan Syariah Fakultas Ekonomi Islam Universitas Djuanda, Jl. Tol \\ Ciawi No. 1, Kotak Pos 35 Bogor 16720, E-mail: rully.trihantana@unida.ac.id \\ 3Program Studi Perbankan Syariah Fakultas Ekonomi Islam Universitas Djuanda, Jl. Tol \\ Ciawi No. 1, Kotak Pos 35 Bogor 16720, E-mail: t.rifqy.thantawi@unida.ac.id
}

\begin{abstract}
Lending Asset Protection Rationale(APLR) is an Islamic bank assessment of the capacity of borrowers to finance permanent corporation that will be given. Assessment of the prospective borrower is basically done not only to the debtor of corporate financing, but only carried out on all the proposed financing of debtors to banks because it is a way in which Islamic banks in implementing risk management financing. APLR done based on the same analytical system in general but has a high level of complexity for large-scale financing and permanent. The method used in this study is empirical juridical research. Results from this study explains the standards and implementation APLR on Corporate financing in Islamic banks.
\end{abstract}

Keywords: Asset Protection Rationale Lending, Corporate Finance, Risk management

\begin{abstract}
ABSTRAK
Penilaian terhadap calon debitur pada dasarnya dilakukan tidak hanya terhadap calon debitur Asset Protection Lending Rationale (APLR) merupakan penilaian bank syariah terhadap kapasitas calon debitur terhadap pembiayaan korporasi yang bersifat permanen yang akan diberikan pembiayaan korporasi saja namun dilakukan pada seluruh pembiayaan yang diajukan debitur pada bank karena merupakan cara yang dilakukan bank syariah dalam menerapkan manajemen risiko pembiayaan. APLR dilakukan berdasarkan sistem analisis yang sama pada umumnya namun memiliki tingkat kompleksitas yang tinggi karena skala pembiayaan yang besar dan bersifat permanen. Metode yang digunakan dalam penelitian ini adalah penelitian yurids empiris. Hasil Akhir dari penelitian ini menjelaskan mengenai standar serta implementasi APLR pada pembiayaan Korporasi di bank syariah.
\end{abstract}

Kata Kunci: Asset Protection Lending Rationale, Manajemen Risiko, Pembiayaan Korporasi

Rani Alfiani. 2018. Implementasi Asset Protection Rationale Pada Pembiayaan Korporasi di Bank Syariah (Studi Bank Syariah Mandiri). Jurnal Nisbah 4 (1): 1-21. 


\section{PENDAHULUAN}

Pembiayaan atau pendanaan merupakan salah satu cara yang biasa dilakukan oleh perusahaan dalam mempertahankan kegiatan bisnisnya. Pembiayaan yang dilakukan oleh perusahaan dapat dikategorikan menjadi dua bentuk yakni Pembiayaan ritel yang biasanya merupakan pembiayaan konsumtif sedangkan pembiayaan korporasi merupakan pembiayaan yang diperuntukan untuk kegiatan produktif suatu perusahaan dengan jangka waktu sementara dan permanen. Pembiayaan korporasi yang dilakukan bank syariah dapat dikategorikan dalam tiga kategori yaitu: Asset Convention Lending, Cash Flow Lending, dan Asset Protection Lending sesuai dengan waktu dari pengembalian dan bentuk pembiayaan yang diberikan (Trihantana, 2015: 1-20). Dari berbagai kategori pembiayaan korporasi yang dilakukan oleh bank syariah Asset Protection Lending (APL) merupakan pembiayaan yang memiliki keuntungan yang besar bagi bank karena bersifat revolving atau evergreen namun memiliki risiko yang tinggi, oleh karena pembiayaan ini merupakan pembiayaan modal kerja yang sifatnya permanen maka bank menetapkan Asset Protection Lending Rationale (APLR) atau penilaian terhadap kapasitas dari debitur dalam menjalankan kewajibannya dengan pertimbangan berbagai unsur. APLR disetiap bank ditetapkan berbeda-beda namun masih berdasarkan standar utama yang di tetapakan oleh Otoritas Jasa Keuangan (OJK) hanya saja bank syariah menyesuaikan penetapannya sesuai berdasarkan kegiatan usaha dan keadaan yang dihadapi oleh bank tersebut.

Penerapan APLR pada pembiayaan korporasi terlebih pada pembiayaan modal kerja permanen diharapkan agar bank syariah dapat memastikan proses dan jalannya pembiayaan berjalan dengan baik tanpa ada masalah, Selain itu pembiayaan ini merupakan pembiayaan korporasi yang pelunasannya bersumber dari kegiatan Asset Conversion Cycle (ACC) oleh karenanya pelunasan tidak diharapkan segera selama perusahaan masih berjalan atau beroperasi dengan baik (Trihantana, 2015: 18). Pelaksanaan pembiayaan korporasi dengan Asset Protection Lending Rationale dilakukan sesuai dengan standar usaha bank syariah yang mengacu pada peraturan BI atau OJK yang dilakukan sebagai salah satu tindakan bank dalam manajemen risiko pembiayaa. Maka dari pemaparan inilah penulis tertarik untuk meneliti kesesuaian penerapan Asset Protection Lending Rationale dengan standar pelaksanaannya pada bank syariah.

\section{MATERI DAN METODE}

\section{Bank Umum Syariah}

Bank Umum Syariah (BUS) adalah lembaga yang menjalankan kegiatan usaha berdasarakan prinsip syariah dalam kegiatannya menawarkan jasa lalu lintas pembayaran. BUS merupakan badan usaha yang sejajar dengan bank umum konvensional yang berdiri sendiri badan hukum berupa PT (Perseroan terbatas), Perusahaan Daerah, atau Koperasi. BUS dapat menjadi sebagai bank devisa atau bank nondevisa.Di Indonesia BUS melakukan kegiatan operasi sebagai Bank Umum Syariah sebanyak 12 bank.

Daftar dari BUS di Indonesia sudah semakin banyak seiring dengan perkembangan aktifitas ekonomi syariah yang tejadi, hal ini juga di karenakan Undang-Undang Nomor 21 Tahun 2008 tentang Perbankan Syariah pada pasal 68 disebutkan bahwa pada Bank Umum konvensional memiliki unit usaha syariah yang mempunyai pencapaian nilai aset paling minim sebesar $50 \%$ dari keseluruhan asset bank induk maka UUS wajib dipisahkan dan menjadi BUS. Berikut ini jumlah BUS di Indonesia. 
Tabel 1. Jumlah BUS di Indonesia

\begin{tabular}{cl}
\hline NO & \multicolumn{1}{c}{ NAMA BANK } \\
\hline 1 & PT. Bank Muamalat Indonesia \\
\hline 2 & PT. Bank Victoria Syariah \\
\hline 3 & PT. Bank BRISyariah \\
\hline 4 & PT. Bank Jabar Banten Syariah \\
\hline 5 & PT. Bank BNI Syariah \\
\hline 6 & PT. Bank Syariah Mandiri \\
\hline 8 & PT. Bank Mega Syariah \\
\hline 9 & PT. Bank Panin Syariah \\
\hline 10 & PT. Bank Syariah Bukopin \\
\hline 11 & PT. Maybank Syariah \\
& Indonesia \\
\hline 12 & $\begin{array}{l}\text { PT. Bank Tabungan Pensiunan } \\
\text { Nasional Syariah }\end{array}$ \\
\hline
\end{tabular}

Sumber: 2015

\section{Pembiayaan}

Pembiayaan dapat diistilahkan dengan "I believe, I trust" yang artinya saya menaruh kepercayaan, berarti bank percaya untuk memberikan pembiayaan pada seseorang dengan melaksanakan amanah. Pembiayaan dalam arti lengkap adalah pengadaan uang atau tagihan yang sejenis dengan itu, berdasarkan kesepakatan atau persetujuan di antara bank dengan pihak lain yang mewajibkan individu tersebut yang diberikan dana untuk membayar kembali tagihan tersebut sampai jangka waktu yang sudah ditentukan dengan bagi hasil sebagai feedbacknya (Kasmir, 2008). Pembiayaan dalam bank dapat dibagi menjadi beberapa jenis sebagai berikut:

1. Jenis pembiayaan dari segi kegunaan

Pembiayaan dilihat dari kegunaannya dapat dikelompokan menjadi dua bentuk seperti, pembiayaan investasi yaitu yang pada umumnyadipakai untuk pelunasan usaha atau membangun proyek/pabrik atau keperluan rehabilitasi dan pembiayaan modal kerja yaitu pelayanan yang digunakan untuk keperluan peningkatan produksi dalam operasionalnya pada biasanya.

2. Jenis Pembiayaan Dilihat dari Tujuan

Pembiayaan dari tujuannya dapat dikelompokkan menjadi tiga bentuk seperti, pembiayaan konsumtif yaitu bertujuan untuk memenuhi kebutuhan dan mendapatkanbarang-barang atau lainnya dengan tujuanpemenuhandalam mengambil keputusan konsumsi, pembiayaan produktif yaitu bertujuan agar memberikan kemungkinan bagi penerima dana mencapai tujuannya jika tanpa adanya pembiayaan tersebut tidak dapat mewujudkan dan pembiayaan perdagangan yaitu pembiayaan yang bertujuan untuk perdagangan yang biasanya diguunakan dalam pembayaran barang-barang dagang dan pegembalian dihasilkan dari penjualan barang dagang tersebut.

3. Jenis Pembiayaan Dilihat dari Jangka Waktu.

Pembiayaan dari segi jangka waktu dapat dikelompokan menjadi empar bentuk seperti, pembiayaan Short Term yaitu pembiayaan jangka pendek dengan jangka waktu maksimal terkecil 1 tahun, pembiayaan Intermediate Term yaitu pembiayaan jangka waktu menengah dengan lebih dari satu sampai tiga tahun, pembiayaan Long Term yaitu pembiayaan jangka panjang dengan waktu lebih dari tiga tahun dan yang terakhir pembiayaan Demand Loan yaitu pembiayaan pada setiap saat dapat diperoleh kembali.

4. Jenis Pembiayaan dari Segi Jaminan

Pembiayaan dilihat dari segi jaminan dapat dikelompokan menjadi dua bentuk seperti, pembiayaan dengan jaminan yaitu pembiayaan yang memiliki jaminan sebagai backup dari pembiayan yang diberikan. jaminan berupa barang berwujud atau tidak berwujud atau jaminan orang, pembiayaan tanpa jaminan yaitu pembiayaan diberikan hanya melihat dari keuntungan usaha, karakter dan loyalitas atau citra diri calon peminjam selama ini.

Adapun akad-akad yang digunakan dalam pembiayaan di bank syariah, sebagai berikut:

a. Akad Wadiah merupakan perjanjian menitipkan dana atau barang dari pemiliknyapada tempat penyimpanan 
atau barang dengan syarat wajibuntuk pihak yang mengelola dana untuk memberikan kembali dana atau barang titipan pada sewaktu-waktu.

b. Akad Mudharabah merupakan pembiayaan/menanamkan dana dari individu yang mempunyai dana (shahibul maal) kepada pengelola (mudharib) untuk melaksanakan kegiatan usaha sesuai kesepakatandan sesuai syariah, dengan pembagian keuntungan atau hasil usaha di antara dua belah pihak didasarkan atas nisbah yang telah disepakati pada awal akad.

c. Akad Musyarakah merupakan perjanjian penanaman dana dari dua individu atau lebih untuk menjalankan usaha sesuai prinsip syariah dengan pembagian nisbah bagi hasil usaha antara kedua belah pihak sesuai kesepakatan,

sedangkankerugiandibagi

berdasarkan porsi modal masingmasing pihak.

d. Akad Murabahah merupakan janji antara dua pihak untuk pembiayaan berupa jual beli barang sebesar harga perolehan barang ditambah dengan keuntungan atau margin yang disepakati, dimana penjual memberi tahu harga perolehan kepada pembeliterlebih dahulu.

e. Akad Salam merupakan perjanjian dua individua atau lebih dalam menjalankan transaksi jual beli barang melalui cara pemesanan dengan ketentuan tertentu dan pembayaran dilaksanakan secara tunai.

f. Akad Istishna merupakan perjanjian berupa transaksi jual beli barang dengan bentuk pemesanan pembuatan barang dengan kriteria sesuai pemesan dan persyaratan yang disepakati serta pembayaran dilaksanakan sesuai kesepakatan.

g. Akad Ijarah merupakan perjanjian antara kedua pihak atau lebih untuk menjalankan sewa menyewa atas barang dan jasa di antara pemilik objek sewa termasuk kepemilikan hak pakai dengan penyewa untuk mendapatkan keuntungan atas pemeliharaanobjek yang disewakan.

h. Akad Qardh merupakan perjanjian pinjam meminjam dana tanpa adanya pengambilan keuntungan dengan kewajiban pihak peminjam mengembalikan pokok pinjaman sekaligus atau cicilan dengan jangka waktu tertentu.

\section{Manajemen Risiko Pembiayaan}

Risiko adalah kejadian yang memiliki potensi baik hal yang dapat diperkirakan (anticipated) maupun tidak diperkirakan (unanticipated) yang berdampak negatif pada penghasilan dan permodalan lembaga keuangan (Nasih dkk, 2013:190). Manajemen risiko yang ditetapkan BI ini bersifat wajib diterapkan karena perbankan syariah merupakan lembaga keuangan dengan potensi timbulnya risiko lebih kompleks dengan lembaga keuangan lainnya. Penekanan pada manajemen risiko tercantum pada PBI No.13/23/PBI/2011 berupa:

a. Pengendalian intern terhadap pelaksanaanoperasional danaktivitas usaha

b. Analisis yang kuat pada setiap pemangku kepentingan

c. Reviewkebijakan manajemen risiko

d. Menetapkan limit pada risiko yang masih bisa diterima bank

e. Pengetahuan yang baik terhadap setiap pekerjaan yang dilakukan sehingga mengerti risiko apa yang akan timbul dan bagaimana cara menanganinya.

Risiko pembiayaan yang terjadi di perbankan syariah akibat dari adanya tenggang waktu pengembalian, maka pengembalian akan menyebabkan adanya kemungkinan risiko tidak tertagih atau macet. Semakin panjang jangka waktu pembiayaan akan semakin bertambah risiko, demikian hal tersebut akan terjadi sebaliknya. Risiko tetrsebutmenjadi tanggung jawab bank, baik risiko disengaja maupun yang tidak disengaja, 
contohnya seperti bencana alam atau disebabkan olehminimnya penghasilan usaha nasabah tanpa adanya unsur kesengajaan lainnya, sehingga tidak memiliki kemampuan untuk melunasi pembiayaan.

Manajemen risiko merupakan satu dari beberapa kepatuhan bank syariah akan peraturan perundang-undangan yang berlaku, hal ini disebutkan dalam Undang-Undang perbankan syariah pasal 38 ayat 1 yakni bahwa pengelolaan dalam mengatur risiko merupakan kewajiban pada bank syariah. Manajemen risiko dilakukan dengan cara mengindentifikasikan, mengukur, memantau serta mengendalikan organisasi agar menghasilkan tingkat risiko yang terarah, wajar, terintegrasi dan berkesinambungan (Karim, 2008: 255). Risiko pada bank syaria dikenal dua macam, yang pertama yaitu risiko pembiayaan yang disebabkan oleh nsabah wanprestasi atau default dan yang kedua risiko pasar yang menjadi penyebabnya adalah pergerakan nilai tukar, risiko akan terjadi apabila pembiayaan yang ditawarkan dalam valuta asing. Oleh karena itu untuk mencegah terjadinya risiko yang terjadi di bank syariah diperlukan penerapan manajemen risiko yang dapat dilakukan dengan melakukan langkah-langkah sebagai berikut:

\section{a. Penagihan Intensif oleh Bank}

Penagihan dilakukan pada nasabah yang memiliki usaha berprospek tinggi dan dianggap masih mempunyai sikap yang baik, tetapi telah menunjukkan tanda-tanda bermasalah dalam pembiayaan. Oleh sebab itu harus diadakan penagihan kepada nasabah secara intensif agar memenuhi semua yang menjadi kewajiban.

\section{b. Rescheduling}

Upaya penyelamatan pembiayaan dapat dilakukan dengan melakukan pergantian syarat-syarat akad pembiayaan yang bekenaan dengan pengaturan pembayaran dana yang telah dipinjam atau jangka waktu, termasuk grace period baik besarnya jumlah angsuran maupun tidak.

\section{c. Reconditioning}

Upaya penyelamatan pembiayaan dengan metode dilakukannya perubahan atas seluruh atau sebagian syarat perjanjian pembiayaan yang tidak terbatas hanya kepada pergantian jadwal angsuran atau waktu pembiayaan saja, akan tetapi perubahan tersebut tidak memberikan tambahan atau melakukan konversi atas seluruh atau sebagian dari pembiayaan menjadi equity perusahaan.

\section{d. Restructuring}

Upaya menyelamatkan dana pinjaman dengan mengganti persyaratan perjanjian pembiayaan atau dilakukan perubahan pada semua atau sebagian dari pembiayaan menjadi modal perusahaan dan modal bank yang dilakukan baik menggunakan rescheduling dan reconditionin maupun tidak.

\section{e. Management Assistancy}

Bantuan meminta pendapat kepada ahlinya dan manajemen profesional yang diberikan oleh pihak bank pada nasabah yang masih berprospek dan memiliki sikap baik untuk membayar semua kewajibannya, tetapi mempunyai kelemahan dalam mengelola perusahaannya, hal tersebut dapat dilakukan dengan cara menyimpan petugas bank atau meminta pertolongan pihak ketiga (konsultan) sebagai anggota manajemen.

\section{Pembiayaan Korporasi}

Pengertian pembiayaan korporasi didefinisikan sebagai seperangkat peraturan yang mengatur hubungan antara pemegang saham, pengurus (pengelola) perusahaan, pihak kreditur, pemerintah, karyawan serta para pemegang kepentingan intern dan ekstern lainnya yang berkaitan dengan hak-hak dan kewajiban mereka atau dengan kata lain suatu sistem yang mengatur dan mengendalikan perusahaan (Bank Mandiri Syariah, 2016). Oleh karena itu, Pembiayaan Korporasi (Corporate Financing dapat 
dikatakan sebagai pinjaman yang diberikan oleh kreditur/bank syariah dan/atau lembaga-lembaga keuangan lainnya yang diperuntukkan bagi debitur/perusahaan yang biasanya berbentuk badan hukum dengan skala besar (korporasi) dengan struktur keuangan yang kuat dalam nominal atau jumlah sangat besar yang pada umumnya pembiayaan ini dalam satuan milyar rupiah. Bank yang melakukan pembiayaan korporasi biasanya di sebut wholeshale banking.

1. Ciri-ciri Pembiayaan Korporasi

Strategi pembiayaan korporasi menggabungkan keputusan suatu perusahaan membuat sekitar struktur modal yaitu, pilihan terbaik campuran utang-ekuitas digunakan untuk membiayai operasinya (Davidson dan Gabriel, 1999:6).Pembiayaan korporasi syariah dapat dibedakan dengan pembiayaan lainnya dengan kriteria sebagai berikut (Trihantana, 2015):

a. Pembiayaan dalam satuan milyar

Pembiayaan korporasi diberikan dalam jumlah paling kecil satuan milyar dan paling besar tidak terhingga sesuai kemampuan bank/kreditor pemberi pembiayaan.

b. Pembiayaan dilakukan oleh senior kreditor

Pembiayaan korporasi biasanya dilakukan oleh senior kreditor karena pembiayaan dengan skala besar tentu hanya dapat diberikan oleh bank/ kreditor yang memiliki asset yang sudah besar pula.

c. Pembiayaan diperuntukan untuk satu proyek atau modal kerja

Pembiayaan korporasi biasanya dilakukan atas dasar pembuatan sebuah proyek seperti pembangunan jalan tol, kegiatan investasi, modal kerja permanen, ekspor-impor, finance company dan lain sebagainya.

d. Dilakukan berdasarkan prinsip syariah Pembiayaan korporasi syariah dilakukan dengan berdasarkan tanpa melanggar ketentuan syariah e. Debitur merupakan perusahaan dengan keadaan keuangan yang tinggi

Pembiayaan korporasi biasanya diberikan kepada debitur dengan keuangan yang besar karena debitur sudah masuk kategori korporasi bukan ritel / eceran.

2. Tujuan Pembiayaan Korporasi

Tujuan adanya pembiayaan korporasi dapat ditunjukkan melalui dua sudut pemikiran yakni tujuan pembiayaan dilihat dari sudut pandang kreditur/bank dan tujuan pembiayaan dilihat dari debitur/nasabah. Berikut adalah tujuan pembiayaan korporasi dilihat dari:

a. Debitur

Tujuan pembiayaan korporasi bagi debitur diantaranya terdapatnya dana untuk peningkatan usaha artinya dapat mengembangkan usaha bagi yang membutuhkan dana tambahan, meningkatkan produktivitas artinya mampu meningkatkan kegiatan produksi perusahaan.

b. Kreditur

Tujuan pembiayaan korporasi bagi kreditur meningkatkan perkembangan kegiatan usaha bank syariah, mempercepat pertumbuhan ekonomi syariah dan meningkatkan tingkat likuiditas bank

\section{Asset Protection Lending Rationale}

Lending Rationale merupakan pemikiran bank syariah secara rasional dalam menilai debitur mengenai kemampuan mengembalikan jumlah pinjamannya kepada bank syariah atau yang biasa dikenal dengan analisis calon debitur. Lending rationale dilakukan berdasarkan proses dalam penerapan manajemen risiko atau salah satu prinsip kehati-hatian bank dalam menilai nasabah untuk diberikan pembiayaan oleh perbankan syariah.

Lending rationale dilakukan untuk mengurangi terjadinya risiko pembiayaan yang dikarenakan terlalu mudahnya bank syariah dalam memberikan pinjaman atau investasi, hal ini dapat didasari karena bank syariah diminta untuk 
memanfaatkan DPK yang diterima dengan maksimal, sehingga penilaian debitur harus dilaksanakan dengan baik (Trihantana, 2015: 1-20, Fitrianti, 2014: 7). Tujuan utama dari Lending Rationale adalah:

a. Mengidentifikasi risiko dalam situasi pinjaman

b. Menarik kesimpulan mengenai kemungkinan pembayaran

c. Membuat rekomendasi untuk jenis yang tepat dan struktur fasilitas pinjaman

Lending Rationale terbagi menjadi tiga:

a. Asset Convertion Lending Rationale

b. Cash Flow Lending Rationale

c. Asset Protection Lending Rationale

Asset Protection Lending (APL)

merupakan pembiayaan korporasi dengan skala besar yang permanen namun menggunakan fasilitas jangka pendek. Kebutuhan permanen ini umumnya berhubungan dengan suatu tingkat kebutuhan modal kerja. Jadi Asset Protection Lending memadukan karakteristik Asset Conversion Lending (fasilitas jangka pendek) dengan Cash Flow Lending (kebutuhan permanen) menjadi suatu bentuk pinjaman yang berbeda dengan Asset Conversion Lending (ACL) dimana kebutuhan pinjaman bersifat sementara dan pelunasan berasal dari selesainya AC Cycle, APL merupakan pendanaan dari AC Cycle yang berulangulang secara permanen terus-menerus. Dengan demikian, Dalam praktiik perbankan konvensional dikenal istilah Kredit Modal Kerja Permanen (KMLP) dan diatur dalam SEBI Nommor 10/18UPK Tahun 1977.(Trihantana, 2015: 13-15).

APLR juga mengharuskan hal-hal sebagai berikut:

a. Pihak bank harus secara akurat mengetahui bahwa nilai likuiditas asset yang dibiayai (jika dijual atau dilikuidasi) dapat menutupi seluruh nilai pinjaman. b. Bank harus berstatus sebagai "senior creditor".

c. Status hukum jaminan harus jelas berada pada pihak bank.

Meskipun pada umumnya APL memiliki jaminan, bukan berarti bahwa jaminan tersebut merupakan sumber pembayaran. Jaminan dalam hal ini hanya dipakai sebagai perlindungan terhadap risiko pinjaman. Contoh-contoh penggunaan Asset protection Lending(Trihantana, 2015: 18) :

a. Pembiayaan modal kerja permanen misalnya: wholesaler, perusahaan export-import, bank, finance company, security broker dan lain-lain.

b. APL dapat dipakai sebagai rationale kedua. Misalnya, dalam suatu CFL degan jangka waktu yang panjang dimana kemungkinan resiko cukup besar.

\section{Karateristik Asset Protection Lending}

Pembiayaan Asset Protection

Lending merupakan pembiayaan sektor korporasi yang bersifat modal kerja permanen. Berikut adalah karateristik APL adalah:

a. Tujuan pinjaman :

Untuk membiayai modal kerja yang permanen.

b. Sumber pelunasan :

Pinjaman tidak diharapkan untuk dilunasi secara penuh selama perusahaan masih beroperasi secara baik. Dalam kondisi yang buruk, asset yang dibiayai dapat dilikuidasi untuk menutupi pinjaman secara penuh.

c. Resiko :

Menurunnya nilai asset sehingga tidak cukup untuk menutupi jumlah pinjaman.

d. Perlindungan :

Nilai dan likuiditas dari asset yang dibiayai.

e. Struktur pinjaman dan pengawasan :

Fasilitas memiliki sifat jangka pendek yang diperpanjang (rollover) terusmenerus. Pengawasan terhadap nilai asset serta kemampuan operasional perusahaan dilakukan terus-menerus. 


\section{METODOLOGI PENELITIAN Deskripsi Penelitian}

Jenis penelitian yang dipakai adalah kualitatif dengan pendekatan metode yuridis empiris. Yuridis empiris adalah penelitian hukum terkait hal yang diberlakukan atau penerapan ketentuan hukum normatif secara in action pada setiap kejadan hukum tertentu yang terjadi di masyarakat (Muhammad, 2004: 134). Sumber data digunakan berupa data primer dan sekunder dengan teknik pengumpulan data melalui observasi, wawancara dan dokumentasi. Berdasarkan masalah penelitian yang akan diangkat oleh peneliti adalah kesesuaian standar dengan implementasi Asset Protection Lending Rationale pada pembiayaan korporasi di bank syariah, maka obyek yang dipilih adalah Bank Syariah Mandiri yang sudah melakukan pembiayaan korporasi dengan Asset Protection Lending Rationale. Sampel yang dipilih dalam penelitian adalah corporate banking division BSM yang menangani mengenai pembiayaan korporasi.

\section{Metode Penelitian}

Metode penelitian merupakan metode yang ilmiah untuk memperoleh data dengan tujuan dan fungsi tertentu (Sugiyono, 2013: 2). Metode penelitian yang digunakan ialah metode yuridis empiris. Penelitian yuridis empiris merupakan penelitan lapangan (penelitian terhadap data primer) yaitu suatu penelitian meneliti peraaturanperaturan hukum yang kemudian digabungkan dengan data perilaku yang hidup di tengah-tengah masyarakat.

\section{Obyek Penelitian}

Obyek penelitian merupakan kumpulan elemen yang berupa individu, organisasi atau benda yang akan diteliti (Dayan, 1986: 21). Obyek penelitian ini ialah Bank Syariah Mandiri yang dipilih untuk memahami mengenai pelaksanaan pembiayaan korporasi secara mendalam, terutama dibagian Corporate Financing
Division yang menangani pembiayaan korporasi di Bank Syariah Mandiri.

\section{Tempat Penelitian}

Tempat penelitian yang dipakai adalah Bank Syariah Mandiri yang beralamat di I, Jl. MH. Thamrin Wisma Mandiri No. 5 Jakarta Pusat 10340 - Indonesia.

\section{Jenis dan Sumber Data}

Jenis data yang digunakan dalam penelitian ini terdiri atas data primer dan data sekunder. Data-data tersebut diperoleh melalui:

1. Data Primer, yaitu data pokok yang menjadi sumber dalam penelitian, dilakukan melalui wawancara, observasi dan alat-alat- lainnya (Arikunto, 2010:145). Data primer akan diperoleh dari hasil wawanca, observasi dan dokumentasi yang didapat dariCorporate Financing Division dan pihak-pihak yang berhubungan langsung dan memahami terhadap pelaksanaan dan permasalahan asset protection lending rationale pada pembiayaan korporasi.

2. Data Sekunder, yaitu data yang digunakan untuk data pendukung dan penunjang dalam penelitian (Arikunto, 2010: 157). Data sekunder diperoleh dari jurnal, buku-buku, peraturanperaturan, internet dan bahan pustaka lainnya yang memiliki keterkaitan dengan penelitian ini.

\section{Teknik Pengumpulan Data}

Teknik pengumpulan data adalah langkah yang paling mudah dalam penelitian, karena bertujuan untuk mendapatkan data walaupun tidak mengetahui teknik mengumpulkan data yang memenuhi criteria standar data yang ditentukan (Sugiyono, 2014: 224). Adapun teknik pengumpulan data adalah:

1. Wawancara

Wawancara (interview) erupakan pertemuan antara dua orang untuk saling menukarkan ide dan informasi melalui tanya jawab, sehingga akan menghasilkan makna yang terperinci dalam topik tertentu (Sugiyono, 2010:410-411). Wawancara yang dilaksanakan peneliti 
adalah interview semi terstruktur, dimana peneliti berusaha menggali informasi yang lebih mendalam tentang objek yang diteliti, sehingga peneliti memperoleh deskripsi permasalahan lebih lengkap dan akurat. Adapun obyek yang akan diwawancarai adalah praktisi-praktisi dan akademis perbankan syariah terutama Corporate Financing Division.

2. Observasi

Hadi dalam Sugiyono mengemukakan bahwa observasi merupakan proses yang kompleks teratur dari pelbagai proses biologis dan psikologis, dua proses yang paling penting dari berbagai proses tersebut adalah pengamatan dan ingatan (Denzin. Lincoln, 2009: 523; Sugiyono, 2013: 196). Observasi adalah kegiatan mengumpulkan data dengan cara pengamatan atas fenomena, gejala dan fakta nyata terkait dengan masalah penelitian (Musfiqon, 2012: 120). Observasi yang digunakan oleh peneliti adalah metode observasi non partisipan. Karena pada penelitian ini peneliti tidak terlibat secara langsung dalam pelaksanaannya hanya mengamati pelaksanaannya saja.

3. Dokumentasi

Dokumentasi merupakan metode mengumpukan bahan atau data yang dilakukan dengan metode mengambil/mengumpulkan gambar, tulisan, atau dalam bentuk lainnya yang merupakan peristiwa yang sudah berlalu, baik secara khusus maupu secara umum yang berkaitan dengan penerapan pembiayaan korporasi dengan Asset Protection Lending Rationale.

\section{Teknik Analisis Data}

Teknik analisis data adalah proses menyusun dan mencari secara tersusun data yang didapatkan dari hasil wawancara, catatan lapangan, dan dokumentasi, dengan mengumpulkan dan menyusun data ke dalam kategori, menjabarkan dalam unit tertentu, dilakukan sintesa, menyusun pada pola, memilih yang penting dan yang dipelajari, dan dibuat kesimpulan sehingga mudah dipahami oleh individu sendiri maupun yang lainnya (Sugiyono, 2013: 333). Adapun teknik analisis data yang digunakan adalah teknik analisis yuridis empiris.

Setelah semua data yang diperlukan terkumpul, kemudian dilakukan pemeriksaan terhadap data baik melalui wawancara dan inventarisasi data tulis yang ada. Kemudian data diolah dan disusun secara sistematis serta menguraikan data atau memberikan interpretasi dalam bentuk kalimat yang baik dan benar (Amirudin, 2006: 168). Berikut ini adalah tahapan analisisnya:

1. Proses transkripsi hasil wawancara secara verbatin atau apaadanya. Setiap transkrip diberi identitas, diperiksa keakuratannya, dan dianalisis.

2. Studi literatur secara mendalamuntuk mengetahui hubungan dan posisi hasil penelitian terhadap hasil-hasil penelitian yang telah ada.

3. Mempertahankan kebenaran hasil penelitian

4. Pertimbangan etik yang meliputi pemberian informasi tentang sifat penelitian, keikutsertaan yang bersifat sukarela, ijin untuk merekam wawancara.

\section{Tahapan Penelitian}

Menurut Moleong ada tiga tahapan pokok dalam penelitian kualitatif antara lain (Moleong, 2005: 85-103)

1. Tahap pra lapangan, yaitu tahap yang orientasinya sebelum turun ke lapangan dengan menentukan fokus penelitian. Dalam tahap ini peneliti melakukan pengamatan pada implementasi Asset Protection Lending Rationale pada pembiayaan korporasi di bank syariah beberapa sumber (modul, jurnal penelitian website dan observasi awal ke Bank Syariah Mandiri)

2. Tahapan kegiatan lapangan, yaitu tahap yang mengharuskan peneliti terjun ke lapangan untuk melakukan penelitian. Pada tahap ini peneliti fokus pada pembiayaan korporasi 
dengan Asset Protection Lending Rationale (APLR) dengan merujuk pada standar baku berdasarkan lembaga regulator.

3. Tahap analisisis data, meliputi kegiatan penelitian dalam mengelolah dan mengorganisir data yang diperolehnya melalui tahaplapangan (wawancara, observasi, dan dokumentasi) kemudian melakukan penafsirandata terkait masalah yang diteliti. Selanjutnya penelitian melakukan pengecekan keabsahandata yang diperoleh dengan uji validitas, reliabilitas, dan objektifitas, sebagai dasar bagi peneliti untuk mendapatkan data yang benar dan akurat.

4. Tahap penulisan laporan, tahap ini dilakukan untuk menyusun hasil penelitian yang diteliti oleh peneliti selama rangkaian penelitiannya. Kemudian peneliti melakukan konsultasi dan bimbingan dengan dosen pembimbing untuk perbaikan dan masukan untuk hasil penelitian yang lebih baik

\section{HASIL DAN PEMBAHASAN}

\section{Gambaran Umum Bank Syariah Mandiri}

Bank syariah mandiri (BSM) adalah lembaga keuangan yang hadir pada 1 Nopember 1999 dengan mejalankan operasionalnya sesuai dengan syariah setelah kesenjangan moneter dan ekonomi pada tahun 1997-1998. Sebagaimana diketahui, krisis ekonomi dan moneter mulai Juli 1997 menimbulkan dampak negatif yang hebat terhadap selutuh sendi kehidupan masyarakat, termasuk dunia usaha, industri perbankan nasional yang dominan dengan bank konvensional mengalami krisis yang besar, sehingga pemerintah pada akhirnya mengambil tindakan dengan merestrukturisasi dan merekapitulasi sebagaimana bank-bank di Indonesia. Tanggal 31 Juli 1999 pemerintah menjalankan penggabungan (merger) empat bank menjadi satu bank baru yang bernama PT Bank Mandiri (Persero) Tbk. Sebagai keputusan merger, Bank Mandiri melakukan konsolidasi serta membentuk Tim Pengembangan Perbankan Syariah yang bertujuan untuk mengembangkan layanan perbankan syariah dikelompokkan perusahaan Bank Mandiri sebagai respon atas berlakunya Undang-Undang Nomor 10 Tahun 1998 yang memberikan peluang untuk melayani perdagangan secara syariah (Dual Banking system).

Pemberlakuan Undang-Undang Nomor 10 Tahun 1998 tentang perubahan atas Undang-Undang Nomor 7 Tahun 1992 tentang perbankan merupakan keadaan yang tepat bagi Tim Pengembangan Perbankan Syariah melakukan konversi PT Bank Susila Bakti dari bank konvensional beralih pada bank syariah, sehingga kegiatan usaha Bank Susila Bakti berubah dari bank konvensional menjadi bank dengan kegiatan operasional dengan dasar prinsip syariah yang bernama PT Bank Syariah Mandiri sebagaimana dicantumkan pada Akta Notaris: Sujipto, SH, Nomor 23 tanggal 8 September 1999. Perubahan kegiatan usaha Bank Susila Bakti menjadi bank umum syariah ditegaskan oleh Gubernur Bank Indonesia melalui SK BI No. 1/24/KEP.BI/1999, 25 Oktober 1999. Melalui Surat Keputusan Deputi Gubernur Senior Bank Indonesia 1/1/KEP.DGS/1999, BI menyepakati adanya perubahan nama menjadi PT Bank Syariah Mandiri.

\section{Kantor Pusat dan Kantor Cabang Bank Syariah Mandiri}

Bank Syariah Mandiri (BSM) merupakan anak perusahaan PT Bank Mandiri (Persero) Tbk. dengan posisi kantor pusat beralamat Wisma Mandiri I, Jl. MH. Thamrin No. 5 Jakarta 10340 Indonesia merupakan pusat kegiatan bisnis yang dilakukan oleh 773 Kantor Cabang di seluruh provinsi Indonesia dengan jumlah modal dasar Rp.2.500.000.000.000,- dan modal disetor 
Rp.2.489.021.935.000,- dengan jumlah karyawan sebanyak 16.648 orang karyawan. Kinerja umum BSM menujukan pertumbuhan yang positif, terlihat dari pertumbuhan yang positif, terlihat dari dana pihak ketiga tumbuh 48,70\% pertahun dan pembiayaan meningkat rata-rata 37\% pertahun. performa bisnis tersebut menjadikan BSM sebagai bank terbesar dan mendominasi pangsa pasar asset perbankan syariah sebesar asset $24,20 \%$, pangasa pasar DPK sebesar $27,50 \%$ dan pangsa pasar pembiayaan sebesar 24,41\% (Sustainabilityreport, 2015:80).

\section{Budaya Pembiayaan Bank Syariah Mandiri}

Faktor penting dalam memitigasi risiko pembiayaan adalah keyakinan Bank atas kemampuan dan kesanggupan nasabah untuk melunasi kewajibannya sesuai perjanjian yang telah disepakati. Hal ini dilakukan antara lain melalui penilaian secara cermat terhadap sifat, modal, kemampuan, prospek usaha, dan agunan nasabah. Kegiatan pembiayaan dilakukan dengan berpacu pada Budaya Pembiayaan Bank Syariah Mandiri, yakni Profesional, Obyektif, Independen, Normatif dan Tanggung Jawab (POINT) yang semuanya bermuara pada Shared Values Bank Syariah Mandiri "ETHIC" yang terdiri atas:(Marzuki, 2012: 10)

a. Excellence (Imtiyaaz): Berupaya mencapai tingkat yang sempurna melalui perbaikan terpadu dan berkesinambungan.

b. Teamwork ('Amal Jamaa'iy): Mengembangkan lingkungan kerja yang memiliki sinergi.

c. Humanity (Insaaniyah): Menjunjung nilai-nilai kemanusiaan dan religius dengan tinggi.

d. Integrity (Shidiq): Mentaati kode etik profesi dan mampu berpikir serta mempunyai perilaku yang terpuji.

e. Customer Focus (Tafdhiilu Al 'Umalaa): Memahami dan mencukupi kebutuhan pelanggan untuk menjadikan Bank
Syariah Mandiri sebagai mitra yang terpercaya dan menguntungkan.

\section{Standar Prosedur Operasional Pembiayaan Bank Syariah Mandiri}

Pembiayan korporasi merupakan salah satu kegiatan bisnis yang dilakukan bank syariah dimana dalam pembiayaan bank menyalurkan dana dari masyarkat kepada debitur untuk kegiatan produktif. Sebelum suatu fasilitas pembiayaan diberikan, maka bank harus memiliki keyakinan bahwa pembiayaan disalurkan akan mendaptkan kembali seluruhnya pembayaran. Keyakinan bank syariah terhadap debiturnya diperoleh dari hasil analisis sebelum pembiayaan disalurkan. Analisis yang dilaksanakan oleh BSM kepada calon debitur/nasabah untuk mendapat keyakinan dengan cara:

a. Solisitasi merupakan salah satu upaya untuk memperoleh informasi tentang kondisi/potensi bisnis daerah/usaha nasabah/calon nasabah. Solisitasi dilakukan oleh Relationship Manager melalui on the spot (OTS) ke tempat usaha nasabah/calon nasabah yang akan atau telah dibiayai Bank.

b. Nota Analisa Pembiayaan (NAP) merupakan media untuk mengusulkan dan menganalisis pembiayaan dari calon/nasabah untuk memperoleh persetujuan komite pembiayaan bank. Penyusunan NAP dilakukan oleh Account Officer Relationdhip Manager (RM) secara sistematis, komprehensif dan informative. NAP dibedakan menjadi dua jenis yaitu NAP Investasi (Form IV.D.1) dan NAP Modal Kerja (Form IV.D.2)

\section{Pembiayaan Korporasi Bank Syariah Mandiri}

Pada tahun 2001 BSM mulai masukpembiayaan sektor korporasi dengan limit awal yang setara dengan bussenis banking atau komersial pada bank lainnya yang bukan syariah. Sektor yang dipilih oleh BSM dalam melaksanakan pembiayaan korporasi pun hanya beberapa menyesuaikan dengan limit yang dimilki saat itu seperti jasa-jasa 
kontruksi belum masuk pada segmen kelapa sawit, infrastruktur dan segmen besar lainnya. Launching korporasi dilakukan pada tahun 2000 dengan bagian yang menangani pertama hanya sebanyak tiga orang Corporate Banking Group (CBG) hingga saat ini banyak karyawan pada CBG sebanyak kurang lebih 20 orang dan nasabah outsanding sebanyak 120 account. Minimal nominal pembiayaan korporasi BSM hingga 2017 sekarang sebesar Rp. 10.000.000.000,dan maksimal 75\% dari Batas Minimum Pemberian Dana (BMPD) dengan perhitungan $25 \%$ dari modal yang disetorkan BSM merupakan BMPD. Divisi Pembiayaan Korporasi BSM pertama dibentuk dengan jumlah yang menangani 3 orang untuk hingga saat ini sebanyak 20 karyawan yang ada CBG. Jumlah nasabah korporasi hingga saat ini sebanyak 120 account. Kemudian sejak saat itu BSM mulai sering melakukan pembiayaan korporasi dengan fokus pembiayaan korporasi ditujukan kepada 3 (tiga) sektor besar antara lain: sektor usaha, perdagangan dan kontruksi jumlah pembiayaan mencapai Rp. 23,81 triliun dengan kenaikan 9,61 dari tahun sebelumnya (BSM, 2015: 95). Fasilitas pembiayaan korporasi yang diberikan oleh BSM merupakan pembiayaan untuk tujuan produktif yang di kategorikan sebagai berikut:(Nasution, 2012: 20)

a. Pembiayaan Investasi adalah pembiayaan dengan jangka waktu menengah dan jangka panjang yang diberikan untuk digunakan membeli barang modal atau asset tetap, pembiayaan proyek baru atau proyek perluasan perusahaan, misalnya mesin-mesin, bangunan, alat-alat berat dan kendaraan. pembiayaan investasi di BSM menggunakan akad murabahah, IMBT dan MMQ di sesuai dengan kebutuhan pembiayaan nasabah.

b. Pembiayaan Modal Kerja adalah pembiayaan jangka pendek yang ditawarkan untuk memenuhi kebutuhan modal calon nasabah atau nasabah. Contohnya seperti untuk mendanai pembelian bahan baku, modal kerja, siklus/perputaran usaha, dan pembiayaan kontraktor. Pembiayaan modal kerja terbagi dua yaitu :

1) Pembiayaan modal kerja biasa sesuai dengan proyek

2) Pembiayaan modal kerja Pembiayaan Dana Berputar

c. Trade Finance, yaitu pembiayan yang diberikan untuk membiayai kegiatan yang berkenaan dengan ekspor-impor, termasuk fasilitas pembiayaan berdasarkan underlying transaction berupa L/C, SKBDN atau sales contract.

Tinjauan Peraturan Otoritas Jasa Keuangan mengenai Standar Asset Protection Lending Rationale pada pembiayaan korporasi di bank syariah

Otoritas jasa keuangan yang mengatur, mengawasi dan melindungi secara khusus tidak mengeluarkan aturan secara khusus mengenai penerapan Asset Protection Lending Rationale pada pembiayaan korporasi di perbankan syariah Indonesia. Namun untuk mengatur, mengawasi dan melindungi kegiatan operasional usaha pada bank syariah agar bank syariah tidak membuat kesalahan dalam penyaluran pembiayaan korporasi dan mengalami risiko dari pembiayaan yang disalurkan. Maka, OJK hanya melakukan pengawasan denganberdasarkan peraturan turunan dari Bank Indonesia yaitu Peraturan Bank Indonesia Nomor 12/23/PBI/2011 tentang penerapan manjemen risiko pada bank umum syariah dan unit usaha syariah.

Peraturan diatas masih berkenaan dengan APLR karena merupakan cara dari mengatasi risiko. Selama APLR yang dijalankan bank syariah dapat membantu dalam mengurangi potensi risiko yang terdapat di bank syariah maka bank dalam melaksanakannya terlebih didukung dengan Undang-Undang Nomor 21 Tahun 2008 tentang perbankan 
syariah pasal 35 yang menetapkan bahwa bank syariah dalam menjalankan kegiatan usahanya wajib menerapkan prinsip kehati-hatian, juga pada pasal 23 yang menetapkan bahwa :

a. Bank syariah harus mempunyai keyakinan atas kemauan dan kemampuan calon nasabah penerima fasilitas untuk melunasi seluruh kewajiban pada waktunya sebelum bank syariah menyalurkan dana kepada nasabah penerima fasilitas.

b. Untuk memperoleh keyakinan sebagaimana dimaksud pada ayat diatas, bank wajib melakukan penilaian yang seksama terhadap watak, kemampuan, modal, agunan dan prospek usaha dari calon nasabah.

\section{Standar Asset Protection Lending Rationale di Bank Syariah Mandiri}

Masuknya BSM dalam pembiayaan korporasi membutuhkan beberapa persiapan seperti kebijakan dalam pembiayaan untuk meminimalisir risiko yang dimiliki BSM terlebih pembiayaan korporasi merupakan pembiayaan dengan skala besar dan dana yang di alokasikan meupakan dana masyarakat yang dititipkan dan dipercayakan pada BSM sehingga bank harus mengelolanya dengan baik. Kebijakan dalam meminimalisir risiko pembiayaan korporasi adalah Asset Protection Lending Rationale (APLR) yaitu keyakinan bank atas kemampuan nasabah untuk melunasi kewajibannya sesuai yang diperjanjikan (BSM, 2012:10).

$\begin{array}{ccr}\text { Untuk } & \text { meminimal } & \text { risiko } \\ \text { pembiayaan } & \text { yang disalurkan, } & \text { bank }\end{array}$ melakukan analisa terhadap pembiayaan pada calon nasabah/nasabah yang akan diberikan pembiayaan korporasi oleh bank. Penilaian bank kepada nasabah dilakukan dengan analisis sebelum pembiayaan dan pengawasan (controlling) saat pembiayaan telah di salurkan hingga pembiayaan tersebut selesai dilakukan.
a. Analisis pembiayaan sebelum pembiayaan disalurkan

Setiap permohonan yang diajukan oleh calon nasabah/nasabah dalam suatu pembiayaan bank harus menilai kemampuan nasabah dalam memenuhi kewajibannya. Penilaian tersebut dapat dilakukan dengan pemberian persyaratan berupa tertulis, lengkap, akurat dan obyektifitas dengan ketentuan:

1) Menilai secara seksama terhadap personal pemohon dengan melihat watak dan kemampuan pemohon berdasarkan informasi yang beredar di lingkungan bisnisnya seperti reputasi nasabah/perusahaan dan profesionalisme pengurus/pemilik.

2) Menganalisis manajemen bisnis/usaha yang dibiayai dengan melihat struktur organisa perusahaan, perkembangan usaha dan grup perusahaan.

3) Menggali semua informasi pemohon yang berkaitan dengan bidang usaha atau proyek yang akan di biayai

4) Menilai agunan (collateral) yang dijaminan pada bank syariah

5) Menilai risiko yang mungkin diambil oleh bank syariah pada pemberian pembiayaan.

b. Pengawasan (controlling) pembiayaan setelah pembiayaan disalurkan

Setelah pembiayaan diberikan bank syariah melakukan pengawasan pada proyek/usaha yang diberikan pinjaman dengan melakukan pengecekan pada laporan perusahaan dan kegiatan yang terjadi. Pengawasan dilakukan sebagai berikut:

1) Mengawasi kesesuaian proses pemberian pembiayaan dengan kebijakan pembiayaan, prosedur pemberian pembiayaan, ketentuan internal bank yang berlaku, dan ketentuan perbankan yang berlaku.

2) Mengawasi kesesuaian pemberian fasilitas pembiayaan dengan ketentuan berlaku untuk menilai kualitas analisis pembiayaan.

3) Memantau perkembangan aktivitas keuangan nasabah termasuk pemantauan melalui kunjungan 
kepada nasabah dan memberikan peringatan mengenai penurunan kualitas pembiayaan.

4) Mengawasi kesesuaian pelaksanaan penilaian kolektibilitas pembiayaan dengan ketentuan yang ditentukan oleh Bank Indonesia.

5) Melakukan pembinaan kepada nasabah untuk selalu memenuhi kewajibannya kepadabank.

6) Mengawasi pengelolaan nasabah bermasalah (dalam perhatian yang khusus, diragukan, kurang lancar dan macet).

7) Memantau dan mengawasi secara khusus kebenaran pemberian pembiayaan kepada pihak yang terkait dengan bank dan nasabahnasabah besar tertentu.

8) Memantau cukupnya jumlah penyisihan penghapusan pembiayaan.

9) Mengawasi penatausahaan

pelaksanaan dokumen pembiayaan.

10) Melakukan penilaian kembali kesesuaian persyaratan pembiayaan yang ditawarkan pada nasabah.

11) Melakukan pemantauan terhadap perubahan yang menyolok baik dari segi finansial maupun non finansial, antara lain:

a) Nasabah lambat atau lalai memenuhikewajiban-kewajiban

b) Sering timbul penolakan cek/bilyet giro

c) Penambahan hutang dagang dan persediaan barang yang cukup besar

d) Perubahan dalam product mix maupun strategi pemasaran Manajemen yang selalu berubahubah.

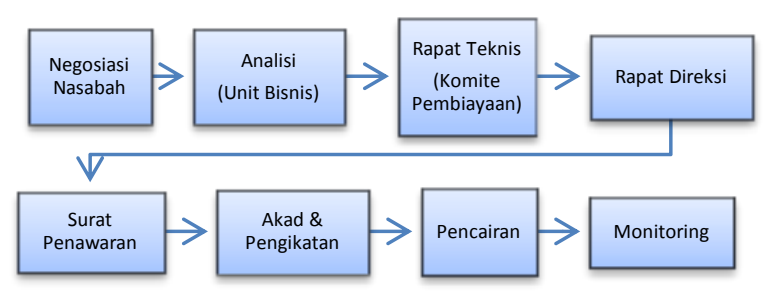

Pembiayaan Korporasi
Sumber: Azhari Maulidin, Operation Corporate Financing, 2017

Prosedur pembiayaan korporasi yang dikutip dari wawancara pada bagian Relationship Manager CBG 2 bahwa proses pembiayaan korporasi dilakukan oleh BSM dilakukan dengan melakukan penawaran kepada korporasi dan hampir tidak ada pengajuan secara langsung dari calon nasabah. Prosedur ini dilakukan agar BSM dapat mengontrol risiko yang mungkin hadir dalam pembiayaan korporasi yang di salurkan. Prosedur pembiayaan yang dilakukan oleh BSM dengan rentang waktu satu sampai tiga bulan sampai pembiayaan tersebut dapat dicairkan. Waktu dalam pencairan korporasi tersebut digunakan BSM untuk menganalisis perusahaandengan mementingkan tujuh aspek yaitu aspek Legal, karakter dan Manajemen, Trect Record, Tehnikal, Pemasaran, Keuangan, AMDAL sosial ekonomi dan Agunan.

Proses analisis yang dilakukan BSM dilakukan secara berulang-ulang dimulai dari unit bisnis sampai dengan direksi dan para pemangku kepentingan hal ini dilakukan agar pembiayaan yang disalurkan pihak bank BSM berjalan dengan baik sampai dengan pelunasan kembali. Prinsip kehati-hatian bank syariah dalam pemberian pembiayaan memperhatikan: (Marzuki, 2012: 15-20) a. Prinsip Dasar Pemberian Pembiayaan

Prinsip dasar pemberian pembiayaan adalah bank harus memerhatikan ketentuan pokok regulator serta prinsip syariah, bank melakukan hubungan dengan debitur yang memiliki karakteristik baik serta memiliki integritas dan tanggung jawab terhadap pemenuhan kewajiban, bank tidak diperkenankan mengorbankan kualitas pembiayaan semata-mata karena target, keuntungan tinggi, gengsi dan kepentingan pribadi, bank tidak memberikan pembiayaan diluar kemampuan sepervisi dan monitoring pembiayaan tersebut, bank diutamakan memberikan pembiayaan dengan valuta 
yang sama dengan valuta sumber pengembalian, bank harus melakukan pemeriksaan atas data-data nasabah yang diberikan kepada bank, selanjutnya keputusan pemberian didasarkan atas permohonan dan evaluasi tertulis baik kualitatif maupun kuantitatif.

b. Prinsip Pemisahan Fungsi (Four-Eye Principle)

Pemisahan Fungsi diartikan sebagai setiap orang dalam jabatan tidak mempunyai kesempatan untuk melaksanakan dan menyembunyikan penyimpangan atau kesalahan dalam pelaksanaan tugasnya pada semua jenjang organisasi dan langkah kegiatan operasional.

c. Prinsip One Obligor

Prinsip one obligor pada dasarnya risiko satu debitur mempengaruhi risiko yang tergabung dalam kelompok usaha, risiko satu debitur dipengaruhi oleh risiko grup secara keseluruhan dan sebaliknya, satu dari beberapa tujuan pelaksanaan prinsip one obligor ialah fasilitas pembiayaan yang ditawarkan tidak melampaui BMPK untuk menentukan strategi penanganan account yang akan ditetapkan bagi debitur dalam suatu grup debitur.

d. Prinsip Anti Pencucian Uang dan Pencegahan Pendanaan Teroris (APU dan PPT)

Unit kerja pembiayaan pemroses pembiayaan harus melakukkan customer Due Diligance (CDD) dan Enhance Due Diligence (EDD). Hal ini untuk memastikan pembiayaan yang diajukan sesuai dengan profil calon nasabah sehingga mitigasi risiko menjadi optimal

e. Prinsip Penyediaan Self Financing

Prinsip self financing adalah penyediaan dana sendiri yang besarannya ditetapkan oleh bank dalam pemberian fasilitas pembiayaan

\section{f. Prinsip Penetapan Kualitas Aktiva Produktif}

Bank menetapkan kualitas dan klasifikasi pembiayaan sesuai ketentuan BI yang berlaku, kualitas pembiayaan (tunai dan no tunai) dibedakan sesuai ketentuan BI (lancar, kurang lancar, dalam perhatian khusus, diragukan dan macet), penetapan aktiva produktif diatur sesuai dengan kualitas pembayaran.

g. Prinsip Pengawasan Pembiayaan

Penjabat dan pengawasan unit kerja pembiayaan harus dengan aktif dan konsisten melakukan pengawasan pada agar bank dapat cepat mengambil langkah pencegahan dan perbaikan untuk menghindari penurunan kualitas pembiayaan nasabah.

h. Prinsip Penanganan Pembiayaan Bermasalah

Bank mendeteksi secara dini pembiayaan bermasalah atau diduga akan menjadi pemicu permasalahan pada pembiayaan, bank melakukan pembinaan, penyelamatan dan penyelesaian pembiayaan, bank mengupayakan pembiayaan bermasalah, diragukan, kurang lancar dan macet dibawah 5\%.

\section{Standar Manajemen Risiko di BSM}

Penyebab utama terjadi risiko pembiayaan ialah mudahnya pihak bank memberikan dana atau menjalankan investasi karena telalu diminta untuk memanfaatkan likuiditas yang berlebihan, sehingga kurang cermat mengantisipasi berbagai kemungkinan terjadinya risiko. Berdasarkan hal tersebut BSM menetapkanstandar dalam melakukan pembiayaan yang dimaksudkan untuk dapat mengurangi risiko yang dimungkinkan terjadi. Di sisi lain dapat juga dibuat untuk menekan angka Non Performing Financing (NPF) pada bank. Oleh sebab itu bank membuat kebijakan manajemen risiko sebagai berikut (Subari, 2016: 4-6) :

a. Identifikasi Risiko

Bank melakukan identifikasi pertama, melakukan identifikasi pada level transaksional maupun level portofolio, kedua melakukkan identifikasi dengan mempertimbangkan hasil penelitian kualitas pembiayaan berdasarkan analisa terhadap prospek usaha, kinerja keuangan dan kemampuan bayar debitur, 
ketiga melakukan identifikasi untuk kegiatan treasury dan investasi dan terakhir melakukan identifikasi risiko pembiayaan yang berada pada semua jenis produk dan kegiatan yang dilakukan.

\section{b. Pengukuran Risiko}

Bank melakukan pengukuran untuk mengkalkulasikan eksposur risiko dengan menggunakan metode statistik, scoring, risk rating,stress testing dan toolslalu selanjutnya bank mengkaji ulang terhadap pengukuran secara berurutan untuk memastikan sesuai atau tidaknya pendapat, kewajaran, akurasi,dan integritas data.

c. Pemantauan Risiko

Bank melakukan pemantauan risiko untuk mengetahui kondidi setiap debitur pada portofolio bank dengan menggunakan sistem watchlist dan portfolio alert dan selanjutnya melakukan pengkajian ulang dengan berkala.

d. Pengendalian Risiko

Pengendalian risiko untuk mengelola risiko yang dapat merugikan kelangsungan operasional bank, pengelolaan portofolio, penetapan limit konsentrasi dan penetapan tingkat kewenangan dalam proses persetujuan penyediaan dana.

e. Sistem Informasi Manajemen Risiko

Bank mengembangkan dan menerapkan sistem informasi pengelolaan risiko pembiayaan yang mampu menyediakan informasi secara lengkap, tepat waktu dan akurat akurat lalu bank menetapkan jenis dan format laporan yang mencerminkan eksposur risiko pembiayaan sebagai dasar pertimbangan pengambilan keputusan.

f. Sistem Pengendalian Intern

Bank menerapkan prinsip pemisahan fungsi (four eye principle) atau segregation of duties (maker, checker, approven) dalam setiap transaksi.

Implementasi Asset Protection Lending Rationale pada Pembiayan Korporasi

Pembiayan korporasi merupakan salah satu kegiatan bisnis yang dilaksanakan oleh bank syariah dimana dalam pembiayaan bank menyalurkan dana dari masyarkat kepada debitur untuk kegiatan produktif. Sebelum suatu fasilitas pembiayaan diberikan maka bank harus yakin bahwa pembiayaan yang disalurkan dapat kembali seluruhnya. Keyakinan bank syariah terhadap debiturnya diperoleh dari hasil analisis sebelum pembiayaan disalurkan. Analisis yang dilaksanakan BSM kepada calon debitur/nasabah untuk mendapat keyakinan dengan cara menerapkan prinsip 6C dan 7P dengan pemaparan:

1. Analisis $5 \mathrm{C}$ adalah:

a. Character ialah sifat atau karakter seseorang harus dapat dipercayai. BSM mandiri melakukan penilaian terhadap sifat dan watak calon debitur/nasabah dengan melihat reputasi nasabah korporasi artinya debitur selalu menepati janji dan tidak terlibat dengan hal kriminalitas

b. Capacity adalah analisis untuk mencari tahu kemampuan nasabah. BSM mandiri harus mengetahui dengan pasti atas kemampuan calon debitur/nasabah dengan melakukan usahanya dari setiap waktu ke waktu.

c. Capital merupakan merupakan analisis untuk mengetahui keadaan kekayaan yang dimiliki oleh korporasi yang akan menerima pembiayaan. BSM harus mengetahui modal calon debitur selain pada besarnya modal juga pada struktur modal yang dimiliki. Capital dari debitur dapat ditunjukkan dari laporan keuangan perusahaan.

d. Condition merupakan keadaan ekonomi dari wilayah korporasi di berikan. BSM dalam pemberian pembiayaan juga harus melihat keadaan ekonomi saat ini dan beberapa waktu kedepan agar risiko yang didapat dapat diminimalisir.

e. Collateral ialah agunan/jaminan yang diberikan calon 
debitur/nasabah baik jaminan yang memiliki sifat fisik atau nonfisik. BSM juga harus melihat jaminan yang dimiliki oleh calon debitur/nasabah. Walaupun jaminan tersebut hanya dapat dieksekusi dengan keadaan yang paling akhir.

2. Analaisis 7P adalah:

a. Personality merupakan penilaian calon debitur/nasabah dari kepribadian sehari-hari maupun dimasa lalu juga meliputi sikap, tingkah laku, emosi dan tindakan nasabah dalam menghadapi masalah dan menyelesaikannya.

b. Party merupakan klasifikasi nasabah berdasarkan loyalitas, modal dan karakternya sehingga bank dapat menggolongkan nasabah pada golongan tertentu yang mempengaruhi fasilitas kredit yang berbeda dari bank. BSM mandiri menerapkan standar mengenai berapa dana yang harus didapatkan oleh calon debitur/nasabah.

c. Pupose merupakan menilai dari tujuan dalam pengambilan pembiayaan termasuk jenis pembiayaan yang diinginkan. Tujuan pengambilan pembiayaan dapat bermacam sesuai dengan kebutuhan. BSM membedakan pembiayaan sesuai kebutuhan yakni pembiayaan korporasi untuk modal kerja dan investasi.

d. Prospect merupakan penilain bank pada usaha calon debitur/nasabah dimasa yang akan datang apakah menguntungkan atau tidak. BSM perlu melakukan penilaian ini terutama pada pembiaayan korporasi karena bank harus menilai agar bank tidak merasa rugi.

e. Payment merupakan penilaian bank terhadap nasabah mengenai cara calon debitur/nasabah dalam pengembalian pembiayaan yang diberikan. BSM menilai sumbersumber lain yang dimiliki oleh calon debitur/nasabah untuk memenuhi kewajibannya sampai perjanjian selesai.

f. Profitability merupakan penilain bank pada calon debitur/nasabah dalam mencari keuntungan dalam usaha yang dijalaninya. BSM dapat menilai profitabilitas calon debitur/nasabah dengan mengukur keuntungan untuk usahanya dari waktu ke waktu.

g. Protection merupakan penilaian bank terhadap calon debitur/nasabah dalam menjaga pembiayaannya seperti dengan melakukan cover sehingga pembiayaan dapat aman.

Calon debitur/nasabah yang mengajukan pembiayaan syariah pada BSM diharuskan untuk memenuhi persyaratan kelengkapan dokumen yang bersangkutan dengan pembiayaannya dokumen tersebut merupakan bahan analisis diatas yang dilakukan oleh BSM. Kelengkapan dokumen yang dibutuhkan oleh calon debitur/nasabah sebagai berikut:

1. Kelengkapan data dan informasi nasabah

a. Informasi dan data umum nasabah yang meliputi legalitas permohonan pembiayaan, legalitas nasabah, legalitas usaha, data informasi keuangan, Curriculum vitae pengurus, susunan kepengurusan usaha, jumlah modal/saham yang dimiliki, hasil penilaian PROPER, daftar jaminan yang berupa barang, hasil BI checking, data dari rekan bisnis, laporan pengecekan langsung, surat pembayaran pajak, pengisian checklist APU dan PPT.

b. Laporan akuntan dan feasibility studi yang meliputi laporan keuangan audited dengan spesifikasi kelengkapan laporan keuangan akurat. 


\section{Analisis Kesesuaian Standar APLR dengan Implementasi APLR pada Pembiayaan Korporasi di Bank Syariah}

Asset protection lending rationale merupakan penilaian dan pemikiran bank terhadap nasabah yang melakukan pembiayaan penerapan APLR pada masih-masing bank berbeda sesuai dengan Standar Operasional Prosedur (SOP) yang buat oleh lembaga tersebut. Namun masih tetap mengambil dasar pemikiran berdasarkan peraturan yang dibuat oleh regulator dan UndangUndang Nomor 21 Tahun 2008 tentang perbankan. Standar yang dibuat oleh BSM memuat beberapa sumber yang diantaranya: (Marzuki, 2012: 14)

1. Firman Allah yang menyebutkan: "dan hendaklah kamu memutuskan perkara di antara mereka menurut apa yang diturunkan Allah, dan janganlah kamu mengikuti hawa nafsu mereka. Dan berhati-hatilah kamu terhadap mereka, supaya mereka tidak memalingkan kamu dari sebagian apa yang telah diturunkan Allah Kepadamu" (Qs. Al Maidah (5):29)

2. Hadis Nabi, yang berbunyi: "sikap hatihati itu datang dari Allah, sebaiknya sifat ceroboh itu datang dari syetan" (HR. Ath Thabrani)

3. Undang-undang No 21 tahun 2008 tentang perbankan syariah:

a. Pasal 35 menetapkan bahwa "Bank syariah dalam melakukan kegiatan usahanya wajib menerapkan prinsip kehati-hatian"

b. Pasal 23:

1) Bank syariah harus mempunyai kemauan dan kemampuan calon Nasabah Penerima Fasilitas untuk melunasi seluruh kewajiban pada waktunya, sebelum bank syariah menyalurkan dana kepada nasabah penerima fasilitas.

2) Untuk memperoleh keyakinan sesuai yang dimaksudkan pada ayat di atas bank wajib melaksanakan penilaian terhadap watak yang seksama, agunan, kemampuan, modal, dan prospek usaha dari calon nasabah yang menerima fasilitas.

4. Peraturan Bank Indonesia atau regulator perbankan lainnya yang mengatur tentang prinsip kehatihatian

5. Kualitas pembiayaan merupakan salah satu faktor dalam penilaian kesehatan bank

6. Terdapat risiko kredit baik karena faktor internal maupun faktor eksternal (nsabah, kebijakan pemerintahan atau kondisi ekonomi mikro) yang dapat menjadi pengaruh negatif bagi kelancaran pengembalian pembiayaan.

Sedangkan dalam penerapan Asset Protection Lending RationaleBank Syariah Mandiri selalu melaksanakan Asset Protection Lending Rationale kepada setiap calon nasabah/nasabah yang akan dilakukan pembiayaan korporasi. Hal ini dibuktikan dengan adanya :

1. Lembar nota analisa pembiayaan investasi yang memuat mengenai informasi calon nasabah/nasabah yang memohon atas pembiayaan korporasi, penilaian aspek-aspek dalam perusahaan pemohon, laporan keuangan serta kejelasan mengenai pembiayaan yang dimohonkan.

2. Daftar mengenai cek dokumen yang harus dilengkapi oleh calon nasabah/nasabah pemohon pembiayaan yang berisikan seluruh syarah yang harus disiapkan oleh pemohon.

3. Analisis komprehensif

4. Tred checking yang dilakukan BSM kepada supplier, buyer, bank to bank dan corporate to corporate

5. Alur/skema pembiayaan korporasi oleh unit bisnis dan direksi serta dokumen-dokumen lainnya yang ada sebagai bukti bahwa BSM telah melakukan APLR. 
Berdasarkan pemaparan standar dan implementasi yang dilakukan oleh BSM bahwa bank syariah mandiri telah melakukan Asset Protection Lending Rationalepada pembiayaan korporasi dengan sesuai kepada PBI No. 13/23/PBI/2011, booklate OJK tahun 2014 edisi 1 mengenai manajemen risiko pada BUS, Undang-Undang Nomor 21 tahun 2008 tentang bank syariah oleh karenanya Bank Syariah Mandiri telah melakukan implementasi Asset Protection Lending Rationalepada pembiayaan korporasi yang sesuai dengan peraturan yang berlaku saat ini.

\section{KESIMPULAN DAN IMPLIKASI}

\section{Kesimpulan}

Setelah melakukan penelitian mengenai "Implementasi Asset Protection Lending Rationale pada pembiayan korporasi dibank syariah (Studi pada Bank Syariah Mandiri)" maka, penelitian ini dapat disimpulkan sebagai berikut:

1. Adanya standar yang diterapkan oleh BSM dalam pelaksanaan Asset protection lending rationale pada pembiayaan korporasi dalam operasionalnya dilakukan dengan berdasarkan pada Undang-Undang Nomor 21 Tahun 2008 tentang perbankan syariah pasal 35 dan 23 mengenai prudential principle dan peraturan-peraturan regulator yang berhubungan dengan manajemen risiko dan prinsip kehati-hatian untuk mengurangi risiko yang terjadi pada kegiatan pembiayaan. analisis yang dilakukan oleh bank syariah mandiri dalam penyaluran pembiayaan korporasi mengacu pada standar operasional bisnis pembiayaan korporasi yang berlaku sejak tahun 2012.

2. Impelementasi Asset protection lending rationale dalam pembiayaan korporasi di BSM dimulai dari penilaian bank terhadap perusahaan yang akan menjadi debitur, analisis dilaksanakan oleh unit bisnis (Corporate Banking Group) bagian Account Officer pembiayaan korporasi. Analisis yang diilakukan BSM terhadap korporasi yang akan dibiayai meliputi tujuh aspek yaitu aspek legal, asppek karakter dan manajemen, aspek track of record, aspek teknikal, aspek pemasaran, aspek keuangan, aspek amdal,, dan aspek Collateral. Analisis untuk penyaluran pembiayaan korporasi bukan hanya dilakukan oleh bagian unit bisnis, akan tetapi juga dilakukan oleh komite pembiayaan, dan direksi. Setelah direksi menyetujui pembiayaan maka dilaksanakan akad dan pengikatan agunan atas fasilitas pembiayaan korporasi yang ditawarkan BSM, proses analisis, pencairan dan monitoring selama perjanjian bisnis dilakukan.

\section{Saran}

Secara umum implementasi Asset Protection Lending Rationale pada pembiayaan korporasi di Bank Syariah Mandiri sudah dilakukan sesuai menurut undang-undang perbankan syariah dan Standar Operasional Prosedur Bisnis yang ada, namun dari hasil penelitian yang penulis lakukan ada beberapa saran yang penulis sampaikan, diantaranya:

1. Bagi Bank Syariah Mandiri

a. Manajemen risiko pembiayaan yang digunakan oleh Bank Syariah mandiri sudah baik dan harus lebih ditingkatkan lagi manajemennya, agar risiko pembiayaan korporasi di Bank Syariah Mandiri semakin berkurang.

b. Meningkatkan ketelitian dalam menilai kapasitas calon debitur dan perusahaan calon debitur agar pembiayaan dapat disalurkan pada calon debitur yang tepat sehingga tidak terjadi risiko.

c. Pembinaan dan pengawasan juga harus dilakukan secara jelas dan terlaksana dengan baik serta memperhatikan tingkat kolektabilitas pembiayaan sehingga 
bank dapat menghindari pembiayaan bermasalah yang mungkin muncul dalam proses pembiayaan korporasi.

2. Saran untuk Regulator

OJK sebagai regulator selalu memantau implementasi keseluruhan tingkat risiko yang dijalankan bank serta membandingkan dengan kesediaan bank dalam menanggung risikonya. Selain itu regulator juga melaksanakan peninjauan regular pada peeraturan dan proses pengelolaan risiko bank. Regulator mengharapkan bank-bank dapat memakai tiga pilar untuk keseimbangan antara modal ekonomis dengan modal yang sesuai persyaratan. Dengan membaiknya kinerja bank akan memberikan pengaruh stabilitas perekonomian nasional.

\section{DAFTAR PUSTAKA}

\section{Undang-Undang}

Undang-Undang Republik Indonesia Nomor 21 Tahun 2008 tentang Perbankan Syariah.

\section{Buku}

Arikunto, S. (2010). Prosedur Penelian: Suatu pendekatan praktik edisi revisi. Jakarta: Rineka Cipta.

Creswell. W. John. (2016). Pendekatan Metode Kualitatif, Kuantitatif dan campuran (Research Design) Yogyakarta: Pustaka Pelajar. Edisi 4.

Dayan. (1986). Pengantar Metode Statistik II. Jakarta: LP3ES.

Denzin, Norman K. Dan Yvonna S. Lincoln. (2009). Hand Book of Qualitative Research. Terjemahan oleh Dariyatno, Badrus Samsul Fata, Abi, John Rinaldi. Yogyakarta: Pustaka Pelajar.

Kasmir. (2008).Bank dan Lembaga Keuangan lainnya, edisi revisi. Jakarta: PT Raja grafindo persada.

Laksmana, Yuksa. (2009). Cara mudah mendapatkan pembiayaan di bank syariah. Jakarta: PT. Elex meni komporindo.

Moleong, J, Lexy. (2005). Metode Penelitian Kualitatif Edisi Revisi. Bandung: Remaja Rosdakarya, 1990.

Muhammad. (2005). Manajemen Pembiayaan Syariah.Yogyakarta: UPP AMP YKPN.

Musfiqon. (2012). Pengembangan Media dan Sumber Media Pembelajaran. Jakarta: PT. Prestasi Pustakaraya.

Sugiyono, P.D. (2014). Metode Penelitian Kuantitatif Kualitatif dan R\&D

Jurnal Bandung: Alfabeta Bandung.

Amirudin, et.al, (2006). Pengantar Metode Penelitian Hukum. Jakarta: Raja Grafindo Prasada. Hal: 168

Ascarya. Yumanita, Diana. (2005). Modul Bank Indonesia Bank Syariah: Gambara Umum seri kebanksentralan nomor 14. Jakarta: PPSK BI.

Asih, Dewi, Imalia. (2005). Fenomenologi Husserl: Sebuah Cara Kembali ke Fenomena. Jurnal keperawatan Indonesia. Vol. 9. No. 2.

De Meuse, P, Kenneth. Vanderheiden, A, Paul. Betgmann, J, Thomas. (1994). Announced Layoffs: Their Effect on Corporate Financial Performance. Jurnal Ekonomi Internasional. Vol. 33. No. 4.

Hasbiansyah, O. (2008). Pendekatan Fenomenologi: Pengantar Praktik Penelitian dalam Ilmu Sosial dan Komunikasi. Jurnal Mediator. Vol. 9. No. 2.

Muhammad, AbdulKadir. (2004). Hukum dan Penelitian Hukum. Bandung: Citra Aditya Bakti. Hal: 134.

Oktaviani, Meita, Rachmawati. (2011). Fenomenologi Implementasi Corporate Social Responsibility Sebagai Realita Strategi PerusahaanStudy Kasus Pada Pt Apac Inti Corpora Bawen Semarang. Jurnal Dinamika Keuangan dan Perbankan. Vol. 3. No. 2. 
Omelen, A, Davidson. Falokun, 0, Gabriel. (1999). The Impact of Interest rate liberalization on the corporate financing strategies of quoted companies in Nigeria. Jurnal Internasional. Vol. 1. No .2.

Rochmanika, Ridha. Rahman, Fuad, Aulia. (2012). Pengaruh pembiayaan jual beli, pembiayaan bagi hasil, dan rasio non performing financing terhadap profitabilitas bank umum syariah di indonesia.Jurnal Ekonomi.Vol. 2. No. 5.

\section{Sumber-Sumber lain}

Annual report Bank Syariah Mandiri. (2008). Bank Mandiri Syariah. Diakses dari www.syariahmandiri.co.id pada Desember 2016.

Bankir Guide to Secure Lending. (2016). Ace Global Depository. Diakses dari www.ace-global.net pada Desember 2016.

Kamus Istilah Perbankan Syariah (Pembiayaan Korporasi Bank Syariah). (2016). Bank Indonesia. Diakses dari www.bi.go.id pada Desember 2016.

Marzuki, Achmad, dkk. 2012. Kebijakan Pembiayaan. Jakarta: PT Bank Syariah Mandiri
Modul Statistika Perbankan Indonesia. (2016). Otoritas Jasa Keuangan. Volume 14 nomor 10 September 2016. Diakses dari www.ojk.go.id pada Desember 2016.

Nasution, Amran dan Achmad Syamsudin. 2012. Standar Operasional Prosedur Bisnis Pembiayaan Korporasi. Jakarta: PT Bank Syariah Mandiri

Perbankan syariah dan Kelembagaannya. (2016). Otoritas Jasa Keuangan. Diakses dari www.ojk.go.id pada Desember 2016.

Subari, T.E.B. 2016. Manajemen Risiko Kredit. Jakarta: PT Bank Syariah Mandiri

Sutrisno, Wahyudi. (2015). Analisis produk pembiayaan bank syariah sekolah tinggi agama islam negeri (STAIN). Pekalongan: UndangUndang Nomor 21 tahun 2008 Tentang Perbankan syariah.

Statistika Perbankan Syariah. (2016). Otoritas Jasa Keuangan. Volume 14 nomor 8 Juli 2016. Diakses dari www.ojk.go.id pada Desember 2016 Trihantana, Rully. (2015). Manajemen Korporasi dan Sindikasi. Universitas Djuanda FEI. Bogor. 